\title{
Analogy of the Covid-19 crisis and the Bosnian war-siege; psychological, sociological and political security perspective
}

\author{
Faruk Hadžıć ${ }^{1}$ (D) \\ 1 BSc, MSc, Independent Researcher, BOSNIA AND HERZEGOVINA e-mail: faruk.hadzic01@gmail.com
}

\begin{abstract}
The study qualitatively explores the pandemic and Sarajevo War-Siege from the psychological, sociological, and political security perspectives. As a direct indicator of behavioral variability within extreme conditions, the author refers to structural interviews with war-siege participants. The citizens can recognize the 1990s in some manifestations of the pandemic, including crisis staff formation that reflects ethnopolitics (ethnic-political boundaries) rather than instills public confidence. Life in the conditions of radical changes leaves a trace that does not have to be exclusively emotional but cognitive. The state of war-siege meant deconstructing the pre-war way of life and new ways of coping with war conditions. Maintaining routines is a link to pre-war life; continuity of norms and values allows for mental stability maintenance. During the siege, people had an acute perception of space and time. Space was something where the danger came from and the time spent in that space needed to be reduced. We have similar functions during the pandemic, reflecting on people's thoughts. Those who have adequately gone through the trauma that lasted during the siege have adapted well to "extreme" conditions and can develop protective mechanisms. Human thought focuses on the repetitive and familiar in today's world, while some extreme event interprets as the exception; such exceptional events are crucial in creating the future. Regardless of the political system's axis, confidence in the political elites must be sufficient. Prevention of fear and panic in the war's geographical area should be based on quality peacetime preparation through education and psychological commitment.
\end{abstract}

Keywords: War-Siege, Covid-19 Crisis, Bosnia and Herzegovina, Psychological-Sociological Perspective, Political Security, Extreme Conditions, Coping Strategies 


\section{INTRODUCTION}

The long term war siege is one of the most harmful, hostile space. The specific circumstances of Sarajevo's citizens' lives under siege (1992-1996) have health, sociological, spiritual-religious, material, and longterm political implications for every individual's life in the country. In the world's most prolonged siege, Sarajevo, 18,889 civilians were killed and died, of whom more than 1,600 were children. With experiences from the not-so-distant past, the citizens of B\&H (Bosnia and Herzegovina) can recognize the spirits of the 1990s in some manifestations of dealing with the COVID-19's threat, including the restrictions on movement, the formation of crisis staffs that often reflect ethnopolitics rather than instill public confidence and respect.

The author suggests how people fought the war and the long war sieges in isolation, without electricity, water, food, heating, gas, developed easier coping with the COVID-19 pandemic. Simultaneously, the latest Gallup research (2020) shows that the citizens of $\mathrm{B} \& \mathrm{H}$ are among those in the world who, in the largest number, 72 percent, believe that the pandemic is not as terrible. Such an attitude towards a global catastrophe can be explained by the experience from the war of the 1990s. In B\&H conditions, every social process that is restrictive in any way brings society into retraumatization. Many people have open and never processed traumas, followed by new ones. Untreated trauma is predicted to worsen the underlying condition, both physical and mental. Psychological competence, which emerges gradually in times of peace, often associated with life crises, becomes a matter of survival in war. While in peace, psychological competencies help us orient ourselves in the world; in war, these techniques help us keep a sustainable inner world despite unbearable external circumstances. (Maček, 2009)

The Covid-19 has changed the world in a way that was difficult to imagine until a few months ago, and research shows that climate change could do something similar. Thus, climate change will not be as fast as viral, but there will be no solutions or relief for them shortly, unlike this pandemic. (Schefer, 2020) Moreover, massive floods threatened many people not so long ago and destroyed a large part of the country.

There is no doubt that our prehistoric ancestors had a hard time experiencing and surviving the catastrophic phenomenon, but it is also clear that people of later civilizations were no less vulnerable to the traumatic experience. No man is certainly less afraid of tools that have been overcome by the appearance of new, more tightening, and destructive, especially means of war, so those that used to seem harmless to him today. K. Clark gave an excellent example in his book "Civilization": "In the ninth century, looking down the Seine, one could notice the bow of a Viking ship approaching the river. Looking at it today in the British Museum seems like a powerful work of art. to the mother of a family, who wanted to calm down in her hut, the bow must have seemed less comfortable - it seemed as dangerous to her civilization as the periscope of an atomic submarine." (Clark, 1980: 97)

Constant danger, insecurity, the struggle for survival, and the deconstruction of pre-war relations cause a complex mosaic of negative and positive emotions. The war siege itself includes memories of the most monstrous murders. The pre-war everyday life, that is, the life as they knew it, is deconstructed in wartime conditions, the struggle for physical and emotional, and moral survival begins, from which astonishing creativity arises. Everyday life is reconstructed in a way that allows for survival but also resistance. The ability to adapt to increasingly poor and dangerous living conditions is seemingly immeasurable. It is mostly reflected in the construction of the "new normal," i.e., the acceptance of new and in everything, concerning peacetime, abnormal living conditions and situations, without electricity, water, heating, and frequent shelling, as usual, as part of life, something that it has to be done without much thought. Also, routines, culturally shaped ways of satisfying existential and social needs (Povrzanović, 1997) characteristic of ordinary life, and their maintenance, despite everything, are gaining significant importance. In some situations, routines are only adapted to new circumstances, while in others, they are redefined and given new meaning. Thus, it takes another function: continuing pre-war routines enabled people to maintain a sense of dignity and strengthened the will to fight for survival.

Today we have war terminology used by many statesmen worldwide to describe the fight against the pandemic. The fact is that the response to this pandemic is not the same in all countries, nor is it equally compelling. Some countries have shown a high level of societal resilience, such as Germany, some have a high degree of trust in government institutions and consequent adherence to measures and guidelines that the population should follow, such as Sweden. Others have successfully used advanced technologies, such as South Korea, and some have used a combination of repressive measures and population obedience to curb the spread of the virus, such as China. However, 
no matter how successful measures to curb the spread of the virus may be, which at this moment refers not only to its eradication but also to the number of deaths, this crisis will have its "non-medical" consequences (economic, geopolitical, cultural), the effects of which are yet to be seen. In itself, the pandemic may not drive change in the way of developing critical national security strategies.

From the political sociology framework, The author maintains that the vision of a political society in which divided political elites form a political organization considerably narrows the perspectives of observing society and influences alternative policy assessment. It leads to interpretive extremes, which on the one hand, claim that the critical issue of $\mathrm{B} \& \mathrm{H}$ society is the existing (ethnic) political elite, or, on the other hand, that the issue of society is a matter of belated modernization and that the political elite is only a reflection of society, as unfinished structures. Comparing the current health crisis with the state of war has a more profound and potentially catastrophic background. Although the war ended in 1996, the society is still profoundly affected by the scale and extent of the conflict, and the state is still highly polarized along ethnic lines and disrupted by ethnically divided institutional practices in sociopolitical processes. Entity authorities in Republika Srpska - R.S. (one of the two entities of B\&H, the other being the FB\&H) announced the setting up of police checkpoints, more drastic control of movement on the "border" between the entities. The Civil Protection Headquarters of the Livno Canton went a step further: it decided to ban the citizens from entering the territory. Symbolically, these "borders" with the formation of ethnically "pure" states in the state were the cause and impetus for the most significant war crimes. According to the official explanation, dissatisfaction with the crisis staff's work in a crisis is a matter of dissatisfaction. (Slobodna Europa, 2020) In this regard, there is a kind of balance of powerlessness and inability to resolve the social crisis, increasing the government's degree of efficiency and dealing with the pandemic. Only functional institutions can respond to existing and potential security challenges. It implies that citizens' interests, not party interests, should be the basis of political action..

\section{METHOD}

The first stage of the study included an in-depth literature review and critical analysis. Theoretical knowledge and expertise are drawn from political science, political sociology, critical security studies, social psychology, health psychology, peace and conflict studies, history, constituting a robust conceptual framework. As a direct indicator of human behavior variability in "extreme" conditions, the author refers to qualitative research by in-depth interviews with direct participants in the 4-year War Siege and randomly chosen Covid-19 narrators. The narrators participated alone; not within the group settings, nineteen participants, eleven females, eight males, ages twenty - sixty-six, from diverse ethnoreligious backgrounds.

\subsection{The War Siege}

Every war is, by definition, a time of abnormal tendencies in all spheres of human life. Along with terrorism, urban conflict is one of the defining types of political violence in the modern age. The permanence of the perceived memory largely depends on the wealth of details that make up one whole. The aggressor, in measures of cruelty and sadism, found a solution to his pre-prepared plans. The plans were clear: Sarajevo should die, but not immediately, but in doses, in fear, in torment, in hopelessness. The citizens of Sarajevo should be denied everything that life makes life: food and water and sleep and electricity and information and communication and (...)" (Karavelić and Rujanac, 2008: 181). We can state that the inhabitants of Sarajevo, under siege by the forces of the Army of Republika Srpska (VRS) and the Yugoslav People's Army (JNA) from 1992-1996, collectively found themselves under "extreme traumatic stressors." Moreover, today, a memory of "evil" that metamorphosed and was stored subsequently becomes the dominant form of behavior that marks new generations. (Hadžić, 2020: 1)

A strong sense of isolation characterizes life in the besieged city:

As soon as a man has no electricity, no water, you have no (...) you are not in your house; you know that they are around, altogether you feel, like, isolated. Simply because you are powerless to do anything or go somewhere, I do not know either, simply because of the great freedom you have, now you have come to the situation that you are from all sides, and by sea and air and land you are (...) in such a small space where you cannot affect anything but wait for what is going to happen. (female, L.E.)

Pre-war everyday life, that is, life as they knew it, is deconstructed in wartime conditions; the struggle for physical, and emotional and moral survival begins, from which astonishing creativity emerges. Everyday life is reconstructed in a way that allows for survival but also resistance. The ability to adapt to increasingly poor and dangerous living conditions is 
seemingly immeasurable. It is mostly reflected in the construction of the "new normal," i.e., the acceptance of new and in everything, about peacetime, abnormal living conditions and situations, without electricity, water, heating, and frequent shelling, as standard, as part of Life, Something that it has to be done without much thought. Besides, routines, culturally shaped ways of satisfying existential and social needs (Povrzanović, 1997) characteristic of everyday life, and their maintenance, despite everything, are gaining significant importance. War conditions and events under siege change social relations. Within the community, social relations are intensified, cohesive forces and solidarity are strengthened. It strengthens the awareness of interdependence on each other for physical and mental survival. In some situations, routines are only adapted to new circumstances, while in others, they are redefined and given new meaning. For example, drinking coffee together, on the one hand, is a link to pre-war everyday life in which it was an essential part of daily routine, and on the other hand, takes on the function of building social cohesion in new circumstances, where mutual assistance is necessary for survival. The importance of drinking coffee together also speaks to the strengthening and importance of maintaining ties within the community. It is an important social event, which is also a cohesive ritual.

Coping describes the cognitive and behavioral efforts a person makes to manage demands that tax or exceed their resources. Coping is a process in which the individual is continuously reappraising the environmental stimulus and resources to determine whether or not the stressor represents a potential threat. The narrators describe maintaining a coffee drinking routine as "terribly important." I. Maček gives routines another function: continuing pre-war routines enabled people to maintain a sense of dignity and strengthened the will to fight for survival (Maček, 2009). In a situation of direct attack and threat, resistance takes various forms. Some are collective; some are individual. Almost all the city inhabitants continue to live under the newly created conditions that become "new normal" and offer resistance to the occupier through this continuation of life. The best illustration is a woman from a photograph by English journalist T. Stoddart, taken in 1994; while dressed as on a catwalk and with her head held high, she walks past a shelter with sandbags. This photo became famous worldwide, and M.J. did not even know that someone had taken it. "The woman who brought glamor to the war zone" was written below a photo in a magazine. The girl's elegance and beauty were described as the ones that adorned Sophie Loren in the 1960s. (Softić, 2020)
The war was marked by a tremendous amount of destruction in which social fabric, cultural habits, political ideas, moral beliefs, even language were destroyed along with the physical environment (Maček, 2009). War is also a time of cultural change, and therefore a very suitable area for studying culture. Namely, "disorder and disease" - that is, a disorder of the social order - is, in many cases, the key to understanding the healthy, established cultural codes of organized functioning of society." (Povrzanović, 1997: 81). Moreover, cultural change is a process through which normality dissolves and is reconstructed in different life areas: material, psychological, social, ideological, and moral. It shows the understanding of culture as a process: in periods of deep crisis - and the state of war undoubtedly is - its processing is far easier to notice than in periods of well-established repetition of known patterns.

Accordingly, crucial changes in several key areas of life are related to survival, social relationships, resistance, and emotions. Survival refers to providing existential conditions, such as food, water, information, staying in shelters. Changes in social relations are visible in the creation of cohesion within the community. Resistance is an essential place in people's lives in war zones, and it takes various forms, from persistent non-abandonment of a more normal life to art. As the most abstract area of life, emotions also change and adapt to war's conditions, which is especially visible concerning death and home as a symbol of security. Panic, by definition, is the complete decline of group cohesiveness.

"When the War started, life was in front of me," S.L. begins her story. She and her friends were graduating from college at the time. Nothing prepared them for what they would live in their city for almost four years. "Instead of starting to live a real, true life and to realize ourselves as individuals, we were forced to see if we would be alive tomorrow," she says. At first, she added confusion and disbelief, but she soon realized that "the devil had made a joke." She began working as a translator and associate for many television crews reporting from besieged Sarajevo. While sitting in the hotel's spacious lobby, she remembers what the place looked like during the war. "It was a house of resistance when it comes to the media. It was their home, and from here, information was sent every day about what was happening in Sarajevo," she says. This hotel is one of the few located in the city center and was also on the front lines." any media in the hotel, I do not think we would be sitting here today," S.L. added. Tragic news about the deaths and 
sufferings of loved ones has become commonplace. One moment of freedom fell incredibly hard. "Killing my then-boyfriend. When, in fact, you become a target for nothing," says S.L. Although life took place in a shortage of food and water, without electricity and heating, it is the worst feeling of absurdity and horror imposed; she points out. "The feeling of helplessness was the worst and most difficult for me personally at the same time. However, in difficult moments, a person gains incredible strength and tries to find a solution to every situation." That is why positive things from that period can be remembered. "It is human warmth and solidarity that characterized us, and foreign journalists who came here during the war. I think that is one of the most significant values that I do not even see exist today."

"Living during the siege is certainly a valuable experience without which every person could live life, in the sense of not experiencing it, "N.K. said at the beginning of the conversation. He lived to adulthood in the war. The captured city was not an obstacle for his interests, so he developed a love for art during the siege - primarily documentaries and theater. "Art in Sarajevo during the siege helped all of us who practiced it, maintaining the illusion of a normal life," says N.K. However, life was not expected. We have learned to receive hard news intensively and to go over it quickly so that we can endure all those four years." He singled out May 2, 1992, as the most crucial moment for the city during the siege. He says that this is the day when "the fall of Sarajevo was prevented" and that everyone who lived in Sarajevo at that time remembers every detail. "I spent my second May in the shelter of the Home for Children with Special Needs. We spent that night hoping that we would stay alive because the building was hit by at least four or five grenades." Then, he says, he made important life decisions. "All those thoughts that went through my head and today I carry with me as a gift that I received that evening, and the gift was that I stayed alive with my neighbors." One video camera was enough for "my own cosmos" which created with friends in response to the aggression to which they were exposed. "We were lucky to have a video camera. We founded a video group, a group of people involved in video art, "says N.K. The first results came in 1993 at the alternative film festival, organized during the siege. The film won first place. "We are very proud when one was awarded. The prize was one convertible mark for which they could buy one coffee. We shared that coffee, and thanks to the festival, we had a nice day in besieged Sarajevo," says N.K. "Something that each of us who survived should carry as most outstanding is that war is the greatest humiliation a human being can experience. Whether it is a victim or worse if you are a perpetrator," he concludes.

At the end of March 1993, a grenade fell in front of the I.Z. family house. "My five-year-old son M.I. was killed on March 21, 1993," says I.Z. It was difficult for the children in Sarajevo, she added. "The children were eager to play. However, they could not go out because the game ended with the murder of children,", she says. In addition to the fear of being hit by a grenade, the children were also in danger from sniper shots. "Children were killed by a sniper. To wonder what kind of brain a target child could have hit, killed," she says. With a dumpling in her throat, she remembers that her son was looking for a banana two weeks before his death. "I do not eat bananas since then," says I.Z.

In a study presented by Djapic and Stuvland, 78\% of $\mathrm{B} \& \mathrm{H}$ children said they had experienced at least six traumatic experiences during the war. Children who fled the Sarajevo war-siege had less traumatic experiences than children who had to stay (Osmanović and Zvizdić, 2000). Besides, all the complexity of the impact of war on children and adolescents and their layered experience can be captured only through testimonies about narrative form, whether life stories or drawings (Jones, 2013). Until the wars in the Balkans in the 1990s, the children were not a direct target of the war. The indifference of attackers, methods of terrorizing and killing innocent children illustrate war planners' intentions and the war in B\&H's very character. According to previous research, many children were killed on non-combat days and outside combat zones. There were no military targets near the place where the children were killed.

In many cases, two, three, four, and even five children were killed. Thus, children killed in war conflicts are not "accidental victims" because war is not an accidental phenomenon. The non-accidentality of child victims is best confirmed by the humanly devastating fact that many of them were killed by a sniper. Moreover, the territorial-conquering logic of war implies the logic of the "final solution of the ethnic-national question, within the discourse of ethnic-religious ideological framework that managed to impose itself as an ideological guide and the matrix of criminal actions. During one of the war negotiations at the Butmir airport, the negotiator of the Republic of B\&H's government at the time asked Krajisnik, the then president of the Pale Assembly (administrative center of the nascent anti-Sarajevo and pro-Serb Republika Srpska during the war), a war criminal 
convicted in ICTY The Hague tribunal: "How long will you kill civilians in Sarajevo?" He replied, "Until you stop wanting to live with us." (Bajtal, 2015) The author suggests that separating the people is most easily achieved by a crime against children whose task is to produce the level of hatred that will finally stifle any desire for unity and thus ensure the ultimate goal - ethnically clean spaces.

The pain and hatred caused by the crime against children are the best guarantees to the criminalsconquerors that every wish of the survivors for return and togetherness, the logic of painful associations and memories will be stifled. Through audio-video testimonies of children and adolescents during the War in B\&H, the Museum of War Childhood provides insight into children's daily lives in the war-torn area with all its specifics, precariousness, and horrors. Besides, through testimonies of survivors, it is possible to retrospectively identify protective factors that helped strengthen resilience in surviving children.

The emotions were more intense than in peacetime. In Sarajevo, people who were too scared and sat in the basements were called "cellars." So much fear was considered a weakness, while just staying in the basement was considered absurd because there is no way you can protect yourself in war. The attempt to completely protect themselves, in addition to being in vain, made the lives of these people even more restrictive, and the resemblance to everyday life, which was so important, wholly disappeared.

(Maček, 2009). For most people, the shelter was a second home. Emotions are not just an individualpsychological experience; they are cultural facts. Culture gives meaning and value to emotions or neglects or suppresses them. Therefore, the meaning of emotions is given to our life in society. In other words, emotions are a culturally shaped social life, constitutive social relations (Povrzanović, 1997). Psychological competence, which emerges gradually in times of peace, often associated with life crises, becomes a matter of survival in war. While in peace, psychological competencies help us orient ourselves in the world; in war, these techniques help us keep a sustainable inner world despite unbearable external circumstances. Life in war conditions on a personal and emotional level is a very intense period. Constant danger, insecurity, the struggle for survival, and the deconstruction of pre-war relations cause a complex mosaic of negative and positive emotions. Among the negative emotions, fear prevails and frustration, helplessness, anger, rage, resentment, hopelessness, uncertainty, concern, isolation, abandonment, disappointment, and to a lesser extent, hatred. At the same time, feelings of solidarity, hope, togetherness, and motherhood prevail.

"Well, those intense feelings, even then your sense of patriotism intensifies, your sense of motherhood and responsibility also intensifies, I would say that. Help other people, jump on each other, solidarity. Everything in those times was amplified in everything. "(female, J.H.).

Fear and hope were frequently intertwined: Fear in those moments when grenades are falling. And then hope, "no more, this is the last I have experienced." (female, A.J.)

"Anger and frustration were part of everyday life: You are angry because you are powerless." (female, M.N.)

"I was angry when I realized how much people can be perverted and hurt other people, show their strength, the power of weapons, and go back to some killing." (female, S.A.)

The dominant emotion in any war is undoubtedly fear. Fear is one of the most powerful and universally present emotions that accompany an existing or expected danger, a reaction to a threat, an emotion that upsets us. In every fear there is a latent fear of death. Fear can have many faces and backs, as M. Povrzanović writes: "Fear is perceived as humiliation, as a possible cause of discouragement, as the imposition of choices that are resolved by selfless or selfish behavior, heroism or cowardice, as a force that drives and causes irrational behavior, but also as a surprisingly effective incentive to focus the total energy (both individual and group) on the purposeful use of available survival opportunities." (Povrzanović, 1997: 83).

Fear can encourage constructive or destructive behavior, i.e., behavior that helps avoid danger or that which prevents it: "Fear of one's injury and death, but also fear for others ( especially for their children) is a strong motivation for constructive action. Nevertheless, the action can also be devastating. The unbearable intensity of fear can cause psychological breakdown - resignation, lethargy, depression, apathy. Uncertainty created many fears; it could be more painful than a potentially dangerous but clearly defined situation. (Povrzanović, 1997: 88) Fear can have very significant consequences: Fear as a cultural factor can have important social implications for emotions; we affirm or deny our participation consequences to ourselves and others. Thus, acceptance or commitment 
to specific values of the society. In doing so, it is essential to note the range of possible roles of fear. Namely, fear can contribute to the confirmation of previously accepted norms or imposed binding values and norms, but it is also potentially the realization of freedom - freedom of choice and rejection of existing values, and the creation of new ones. Younger people, with no personal war experience, were also in fear of the unknown. Traumatic memories were awakened in the elderly, those who have this experience - old fears were reactivated. (Povrzanović, 1997: 98). Besides, It was acceptable to be afraid in war, even for men who traditionally should not show fear. Given the hazardous circumstances, it was impossible not to be frightened, so social norms adapted to the situation.

The undeniable interests and one of the most urgent needs in war is to adapt to survive, physically and psychologically and culturally, adaptation strategies ideas and actions to eradicate. Thus, fear in the context of ubiquitous war violence - creative are, in the culture of an endangered group (or war-endangered society), a way of dealing with the fear caused by war.

As is the case with other war experiences, for example, in the next narration of taking cigarettes from the traffic during the bombing, fear's experience differed mostly generationally.

"However, fear, I tell you, was not something of fear when you were younger. We had a great run where a bomb fell to see what happened, you understand. "(male, A.B.) Furthermore, the U.N. Commission on Human Rights' Special Rapporteur on former Yugoslavia reports on interviews with children: "Memories of the event remain with (...) causing extreme nightmares, daily intrusive flashbacks of the traumatic events, fear, insecurity, and bitterness. (Mazowiecki, 1994: 34)

There were feelings of hatred and anger related mainly to the attackers but also the international community. "To the international community and our politicians, no one is doing anything like that. Hate and anger. Hatred towards Serbs and anger towards the international community." (female, B.Č.)

Thus, such an opinion prevailed in wartime Sarajevo - Western non-intervention in the War in B\&H was increasingly interpreted as hypocrisy by the West, which liked to talk about human rights but did not care the least about the small Muslim population in Europe. Simultaneously, the Western policy was based on a cynical view of the Balkans' strategic loss of value after the Cold War. (Hadžić, 2020)
The unique Wartime characteristic is that humans inflict suffering on other people while simultaneously depending on each other for physical and emotional survival even more than in peace. The wartime sense of togetherness and solidarity, which is lost after the war, is also specific: "As the neighbors always quarreled, then there were no more quarrels or anything, was somehow. Well, for sure, it was a big, big thing, and every living word will say that, what we had solidarity in the war, what we had to help, all that. "(male, K.K.)

The author notes that in Sarajevo, neighborhood solidarity based on close daily living has reemerged. Nevertheless, as conditions improved, war patterns of socializing shifted back to pre-war ones. However, after the imminent danger has passed, communion is replaced by the enrichment of some and others' impoverishment.

"Afterwards, reckless reality came in its way. They began to quarrel with each other as if we were doomed to eternal damnation. Those who fled with their greed and money tore down the magical but fragile tower of friendship. They tried their best to get rich, and they succeeded." (Vukojević, 2010: 43).

The unique economic feature and the most significant impetus for strengthening criminal networks in the Balkans was the tremendous economic opportunity offered by weapons or other war goods, such as fuel and international humanitarian aid appropriation. Despite the "Western neutrality" for material support to the parties in the struggle and thus prolonging the conflict, humanitarian aid that was salty was taken away during that period by many warlords, who did not differ, for example, from Somali fractions. In the past, international humanitarian discourse from similar experiences in Somalia has not been sufficiently understood. Even in the case of the earth's implosion, the trigger was a sudden "collapse of strategic value." (Hadžić, 2020: 42)

The following narration shows that crises, such as war, are a time when people show their real face: "Yes, in extreme situations, they steal, cheat, run away, or provide some benefit for themselves, or they are maximally altruistic and help everyone, comforting, I do not know (...) All in black and white. There was no middle ground. Exactly (... ) And in emotions, and in socializing, and so on. Either you are good, or everyone will help you, or you will help, or you will, I do not know, look after yourself and some of your benefits. It was just, just seen." (female, A.B.) 
"I think war is the right time for man to show his true face. Unfortunately. "[laughs]. (male, K.H.)

Thus, it is one of the complexities of life. People are created to survive in hazardous situations. Some people are very efficient in times of war. Simultaneously, in a peaceful environment, they are outdated or worse, they are monstrous. It is like a story about a crime and punishment written by Dostoevsky.

Although death is an integral part of life, it becomes ubiquitous, every day, and random in war. Emotional responses to death show the adaptation of the psyche to the harsh conditions of war. Death becomes ubiquitous, massive, and random, and in response, it begins to be treated as something "normal." This "normalcy" of death ceases in the direct encounter with the death of loved ones.

From today's perspective, the government has yet to compile a centralized database of all war victims with post-traumatic stress disorder. However, according to a study by the Ministry of Health published in 2012, more than 60 percent of Sarajevo residents suffer from post-traumatic stress disorder symptoms, while 73 percent of them suffer from problems caused by stress. These traumatic stressors are associated with survival and safety. They did not have access to food or water and were forced to live without the influx of information, so they lost touch with the world. Moreover, those suffering from trauma today have suffered a loss of identity, which can manifest itself in intense feelings of helplessness, depression and emotional numbness, even mechanical behavior, persistent depression, and lack of initiative.

\subsection{The Covid-19 Health Crisis}

COVID-19 is a new and as yet unknown disease, which causes people to feel insecure. Due to the media selection of presenting negative news and spreading panic in society and the sudden change in living conditions, it is quite normal and natural for people to react to fear, either for themselves or for their more vulnerable family members. During the pandemic and the constant influx of new information about the number of patients, prevention measures, the general level of anxiety significantly increased. Everyone absorbs it, shifting the focus to the physical signs of the disease. Expert estimates indicate that Italy's high mortality rate was caused by a lack of discipline and social responsibility, a classic Mediterranean approach that is ordinarily charming, and in these extraordinary circumstances, it is hazardous. Data from cities across $\mathrm{B} \& \mathrm{H}$ shows that the police have much work to do against violating the imposed measures. (Mušić, 2020) Besides, many people feel threatened due to existential problems, work stoppage, self-isolation, or quarantine. However, the world's struggle in this field does not mean that other struggles have been stopped. People who have mental problems still face anxiety, panic attacks, psychotic symptoms. We must not forget them and the battles they fought before the pandemic began. Situations of increased stress, wars, natural disasters, including a pandemic as a significant global health crisis, can trigger deterioration in people with mental health problems, even if they were previously stable. An analysis of 65 studies showed that among patients with SARS, MERS, and COVID-19, 32\% had PTSD, $14.9 \%$ had depression, and 15\% had an anxiety disorder.

Russian psychologists claim that another wave of psychological trauma will be linked to the pandemic's economic consequences. (VNIITF, 2020)

Emotions are a response to events, either internal or external. What emotions then trigger in people with mental health during a coronavirus pandemic? Just because they are in a state that triggers specific emotional processes does not mean that they do not feel the same as all other people, if not more intensely. Due to the conditions they struggle with daily, they can feel low self-confidence, shame, guilt, carry the belief of lower value, inadequacy concerning other people. Helplessness, sadness, the difficulty in recognizing and managing their own emotions, severe anxiety, lack of willpower, inability to die, feelings of insecurity in relationships with other people, pronounced fear of leaving, fear of first hospitalization, overwhelming emotions of sadness or anxiety, are one part of a wide range of emotional feelings, present in everyday life of people with mental problems.

The pandemic has caused social stigma, and discriminatory behavior towards people of a particular ethnicity and anyone believed to have been in contact with the virus. The Guide to Preventing and Addressing Social Stigma Related COVID-19, developed by UNICEF, the World Health Organization (WHO), and the International Federation of Red Cross and Red Crescent Societies (IFRC), states that stigma can undermine social cohesion and accelerate the possible social isolation of the group, which could contribute to a situation where the virus can spread even more. It can result in more severe health problems and difficulties in controlling disease outbreaks. The level of stigma associated with COVID-19 is based on three main factors: the disease is new, and there are still 
many unknowns; we are often afraid of the unknown, and it is easy to connect that fear with "others." For example, stigma and discrimination can occur when people associate a disease, such as COVID-19, with a population or nationality, although not everyone in that population or region is particularly at risk for the disease. Stigma can also occur after a person has been released from COVID-19 quarantine, although it is not considered a risk for the virus to spread to others. The misinformation is spreading faster than the new coronavirus's epidemic, contributing to adverse effects, including stigmatization and discrimination against people.

There is no single point of view on defining a crisis. A crisis can generally be defined as an emerging risk. It had been recognized and valued before or had not been noticed at all, so it performed utterly suddenly. The London School of Public Relations defines a crisis as "a serious incident that affects a person's safety, environment, products, or organization's reputation. "Such an incident is characterized by a hostile attitude of the media towards it. Some authors define the crisis as an unplanned and unwanted process that lasts a particular time, which can only be partially influenced and can end in various ways. D. Jugo defines a crisis as an intense phenomenon with a potentially harmful outcome that affects the organization or the industry as a whole and their public, products, services, or reputation. Other scholars describe the crisis as "a major event with a potentially negative outcome that affects both the organization and its public, services, products, and name." (Jugo, 2017: 78) It interferes with the regular operation of the organization and, in the worst-case, threatens its survival. A crisis is an unplanned and unwanted process that lasts for a certain period, which can only be partially affected and can end in various ways.

Psychology and psychiatry define the crisis as "a short confusion that happens from time to time to people who are struggling with their life problems, which at that moment, exceed their capacities." Due to the growing number of accidents and crises, crisis communication has had a strategic place in institutions' lives in recent years.

The crisis caused by the COVID 19 pandemic has repeatedly affected various spheres of society and individuals. It is a new and unknown experience globally in the modern world, which causes uncertainty, fear, and often a feeling of helplessness. At the individual psychological level, it manifests itself in various ways: from a fleeting feeling of anxiety, confusion, mood swings, the appearance of a catastrophic way of thinking to the activation or reactivation of more severe psychological difficulties.

Different coping strategies are more effective, depending on the environmental demands and available resources. Some coping strategies are directly related to health, such as smoking, drinking, and overeating or undereating. Coping strategies focused on overcoming have two interdependent goals: solving the problem that arose in the encounter of the person and the environment, but they also indirectly serve to improve the mental state of the individual (Chu Lien Chao, 2011). Another large group of coping mechanisms is the so-called coping strategies focused on emotions. They have a common goal: to regulate emotions, maintain hope and optimism, and refuse to accept the worst. Researchers have shown that people are more likely to use (with considerable success), while emotion-focused mechanisms are more adaptive (Snyder and Dinoff, 1999). There is also coping with avoidance as a unique dimension. It refers to cognitive or behavioral avoidance and denial of the existence of a problem.

Moreover, gender differences might mediate the effects of stress on health in many ways. Stressors could be interpreted differently by men and women. Some research implicates that women seem to report relatively more distress and that physiological response and reported distress levels do not always correspond. Men and women respond to stress differently, with women experiencing more extraordinary sadness and anxiety, while men show a greater integration of reward motivation (craving) and emotional stress systems.

Psychological trauma is an everyday occurrence in a person's life, most often determining his destiny's uncertain paths. There is no doubt that our prehistoric ancestors had a hard time experiencing and surviving a natural catastrophic phenomenon, but it is also clear that people of later civilizations were no less vulnerable to the traumatic experience. No man is certainly less afraid of tools that have been overcome by the appearance of new, more frightening, and destructive, especially means of war, so those that used to seem harmless to him today.

F. Furedi (2006), a sociologist, argued that today's culture of fear did not begin with the collapse of the World Trade Center. The very use of the term "War on Terrorism" was intended to create a culture of fear intentionally because it "obscures reason, amplifies emotions, and makes it easier for demagogic 
politicians to mobilize the public on behalf of politicians they want to pursue." (Brzezinski, 2007: 1) Thus, ideas about safety and controversy over health, the environment, and technology have little to do with science or empirical evidence but are shaped by cultural assumptions about human vulnerability. Propaganda can significantly outweigh the media effect already produced by traditional media and communication (satellite T.V., newspapers, radio) and cause even more significant menacing consequences than those caused by terrorist attacks themselves (e.g., the spread of

news and attack on communications infrastructure). The benefits of the stock market can lead investors to panic and, consequently, lead to a small them saves money to behave irrationally, inflicting even more significant economic damage than the damage to the material infrastructure itself.

The author suggests that rapid adaptation to situations where expectations deviate, situations that others see as high anxiety situations, and people who have gone through war or siege in such situations can function much more comfortably. They can think logically in such situations without some anxiety pressure. Then, it depends a lot on the context in which people experience the pandemic. The author maintains that reflected in contexts where there is an intense, almost acute anxiety about social interactions. At the same time, multiplied fears create collective paranoia. However, it is too early to say what sense of life during a pandemic can affect human behavior changes. If there were a pathology, it would intensify; if there were domestic violence, it would intensify; if someone has an anxiety or depressive disorder, it could intensify. Therefore, a depressed mood or even the appearance of a clinical picture of depression can be expected.

It is essential to distinguish the depressed mood, which will pass with the release from isolation, from depression, as a form of a more severe disorder of a person's mental functioning, which does not change the course with the release from isolation. The decline in mood, loss of interest, occasional black thoughts, negative attitudes towards society, and the situation are understandable and expected. However, if this condition becomes permanent, if there is hopelessness, complete depression, refusal of contact, refusal of food, lack of personal hygiene - all these are symptoms of clinical depression, and for such symptoms, people should urgently consult a physician. Psychological competence, which emerges gradually in times of peace, often associated with life crises, becomes a matter of survival in war. While in peace, psychological competencies help us orient ourselves in the world; in war, these techniques help us keep a sustainable inner world despite unbearable external circumstances. (Maček, 2009) Thus, Covid-19 has changed the world in a way that was difficult to imagine until a few months ago, and research shows that climate change could do something similar. Moreover, not so long ago, there were significant floods, which threatened many people and destroyed a large part of the country.

Narrators do not perceive the pandemic as such a great danger, while at the same time, the Statistics of the number of infected and deaths change daily.

"Dear God, all normal states stopped testing because they realized that this is a scam; only our deacons will test us until the judgment day. However, there is money. "(female, J.H.)

“The WHO (World Health Organization) is a mockery and a disgrace to humanity. Sweden is the law; they get natural immunity and still save the economy and nerves, while in the Balkans, they handled us "from behind" and made parties and violated regulations themselves. They also robbed." (male, N.K.)

"The more infected, the more money they will get from the E.U. The same thing is with the migrant crisis. They did not prevent the migrant crisis because of the more migrants, the more money from the E.U. Typical SDA (The Party of Democratic Action- Bosniak political party) policy. "(female, S.P.)

“The media complicates it." (male, H.A.)

"God forbid that the state protects our mental health (...) Naked people would jump in the parks." (male, J.S.)

"Ok, reducing social contacts is quite logical, but why are those who have been diagnosed with the Covid and do not have severe symptoms sent home to infect their families as well? Not everyone has the opportunity to isolate themselves from grandparents, wives, and children. Moreover, their families have to go to the pharmacy and the store, which only spreads the virus. Put the sick in a hotel or particular room; otherwise, this state of emergency will last three years." (female, A.B.)

The political elite is a crucial variable for adequate political security and social and political change. Political instability is the primary focus on certain parties or entities' politics, neglecting the state. It received significant proportions, which ultimately 
led to the fact that the political alternative could be imagined only in the given elite parameters and in no other way. Society is still profoundly affected by the scale and extent of the conflict, and the state is still highly polarized along ethnic lines and disrupted by ethnically divided institutional practices in politics and society. It means that it is not just a crisis of relations between political parties but also a fundamental weakness of the socio-political factor. Most of the sociological data obtained through various surveys in recent decades show a more massive gap between the political elite and citizens than between citizens based on their ethnicity. Regardless of the political system's axis, confidence in the political elite is at a deficient level. It is mostly a reflection of the country's consociational order that prescribes such a vertical relationship and produces a democratic deficit, diminishing the relevance of civic participation in politics and leaving the political elite solely responsible for political decision-making processes. It often leads to the challenge of falling into a kind of affective discourse about the political elite, which presupposes researchers' higher moral position for an analytical judgment.

For the last twenty years, A.H. has been working on projects to deal with war veterans' past. He survived a nearly four-year siege of Sarajevo and said the war is a much worse experience, which has fundamentally changed society as a whole. "It has changed people, including me. Nevertheless, every significant tectonic change affects both individuals and groups, with war being a more emotional phenomenon for me and tied to political identity. It is different again, we have a chance for solidarity, and maybe it makes us wiser to take care of both the environment and health," he says, adding that people will be more changed by the socio-economic problems that follow. D.J. agrees with that assessment. In the USA, where he now lives, he says the most important thing is that he and his wife kept their jobs. (BNN, 2020) When it comes to getting used to a pandemic state, it means that we no longer perceive it as such a great danger.

Taking care of mental health during conflicts and other emergencies, particularly in countries where such support is limited, can lead to identifying people who are in some way hidden from society. In many cases, this support helps dispel myths about mental illness and leads to treatment and care and the path to a more dignified life. That our defense mechanism to be careful, to be distanced, gives way. When the political will exists, emergencies can be catalysts for building quality mental health services and the community's social cohesion. If we look at the global landscape of mental health services development over the last 20 years, it is fair to say that some of the most significant leaps forward have been made after emergencies. (WHO, 2019) During the current migrant crisis and the Balkan Migrant route, the ethnically fragmented Institutional Structures of $\mathrm{B} \& \mathrm{H}$, within the humanitarian-security framework, have led to a critical situation. (Hadžić, 2020: 16)

There is an absolute correlation between democracies' power and stability, i.e., defective democracies and instability within extremist ideas' tolerance as collective behavioral patterns characterized by the Western Balkans mentality local historical and current circumstances implies antagonism to the most dramatic conflicts. (Hadžić, 2020: 284) We already problematized the creation of symbolical "borders" with the formation of ethnically "pure" states - the war "Republika Srpska" and the war "The Croatian Republic of Herceg-Bosna" (an unknown geopolitical entity and proto-state proclaimed on November 18, 1991) - were the cause and impetus for the most significant war crimes, with dozens of convictions by the International Tribunal of Former Yugoslavia - ICTY. According to the unofficial explanation: on obstruction in the procurement of necessary medical equipment to fight the coronavirus virus. (Ministry of Health, 2020) In this context, the pandemic also refers to cooperation and solidarity instead of threats.

\section{CONCLUSION}

People change during crises because they are suddenly forced to live in different conditions. Life in radical changes leaves a trace that does not have to be exclusively emotional but can also be cognitive.

Psychological trauma is an everyday occurrence in a person's life, most often determining his destiny's uncertain paths. In war, maintaining mental stability is necessary for survival. Psychological competence must be built quickly, unlike in peacetime, when it gradually develops. Negative prevailing emotions such as frustration, helplessness, anger, rage, resentment, hopelessness, uncertainty, worry, isolation, abandonment, disappointment, hatred are opposed to feelings of solidarity, hope, togetherness, motherhood as positive emotions. Social norms of solidarity, mutual aid, hospitality, and reciprocity competed with opposing forces of selfishness, corruption, theft, war-profiteering, and the black market. Apart from the level of survival and satisfaction of basic life needs, deconstruction also occurs in social relations; communities show solidarity, cohesive forces are 
strengthening, and social relations are intensifying. Simultaneously, the culture determined the rules for using emotions as a means of communication, defining their desirable and permissible intensity and the forms of their expression.

In addition to the constant news of others' deaths, people are frequently confronted with their mortality during the war. In wartime conditions of destruction, life itself becomes resistant, as closely as possible to pre-war standards of normalcy, meant to show defiance and active resistance. Maintaining routines is a link to pre-war life, continuity of norms and values, and on the other hand, allows for the maintenance of mental stability. Often, creativity and innovation make up for what is lacking and give birth to a specific resistance form, and no less requires life in a time of the pandemic. Simultaneously, following previous experiences and the very structure of the personality, people face the crisis in their way; that is, they choose their coping mechanisms.

Strategies for dealing with a crisis should include: defining the problem, looking for alternative solutions, weighing these possibilities concerning the expected outcomes. Thus, choosing a solution and taking action. Moreover, within the gender discourse, men and women may employ different coping strategies.

In a planned and systematic manner, children were killed within the ethnic-religious framework that imposed itself as an ideological guide and the matrix. The criminal's pathological degree and psychological profile can hardly be explained by the usual interpretation patterns available to our time's scientific psychology and psychiatry. By illustrating the experiences of $\mathrm{B} \& \mathrm{H}$ children and adolescents, a better understanding of life in and after the war can be helped, and this knowledge can be used to protect children now living in conflict zones and increase the global chance of survival and lasting peace.

Emergencies are possible in the modern human community and wars, and therefore programs of preventive activities should be implemented. Prevention of fear and panic in the general population in the geographical area affected by the war should be based on quality peacetime preparation through education and psychological commitment to face and survive a presumed war or natural disaster. The absence of a mass occurrence of intense fear and panic diminishes the effects of catastrophic consequences in emergencies.
During the siege, people had an acute perception of space and time. Space was something where the danger came from and the time spent in that space needed to be reduced. During the pandemic, we have some similar functions, reflecting on people's thoughts. In a situation of isolation and increased external tension, emotional states can intensify more. Exposure to a large amount of continually changing information about the number of deaths can negatively impact people, especially those with mental health problems. It is a general feeling of loss of control and helplessness, which people with mental problems can otherwise feel over their lives; otherwise, they can fear it (anxiety disorders). It is essential to have the necessary information about their situation.

As for the changes that can cause a pandemic life in the general population, society will undoubtedly change, particularly in the socio-economic framework. Much depends on the context in which people experience pandemic. In contexts in which there is a strong presence, almost acute anxiety about social interactions can be reflected. However, some contexts are not so much affected by the pandemic, where these social interactions would return much faster.

These factors also encourage harmful stereotypes, and the stigma itself can force people to hide the disease to avoid discrimination, prevent people from seeking health care immediately, and discourage them from adopting healthy behaviors. Governments, citizens, the media, and communities play an essential role in preventing and stopping stigma. However, following the isolation measures, the value is to take care of and about others.

This global pandemic is a kind of "shock therapy" with pre-existing challenges shaping the context of the global security environment. The pandemic symbolizes "non-traditional" and non-military threats and emphasizes the need for different anticipation, planning, and approaches to responding to such challenges. Furthermore, regardless of the political system's axis, confidence in the political elites must be sufficient. For B\&H, a crucial segment in the fight against pandemic is current operations or future security planning, emphasizing socio-political pluralism to mitigate effects. Human thought focuses on the repetitive and familiar in today's world, while some extreme event interprets as the exception, and such exceptional events are crucial in creating the future, that is, that the future will be increasingly unpredictable. 
The last three decades' experiences are calamitous in the $\mathrm{B} \& \mathrm{H}$, and war events are still fresh. The citizens can recognize the spirits of the 1990s in some manifestations of dealing with the pandemic, including crisis staff formation reflecting ethnopolitics (ethnic-political boundaries) rather than instilling public confidence respect. The cases and practices of setting ethnic boundaries remind of war, with an understanding of the history of the 1990s, more than the health crisis caused by the pandemic. People who have adequately gone through the trauma that lasted during the war siege, and have adapted well to "extreme" conditions, can develop protective mechanisms.

\section{REFERENCES}

- BAJTAL, E. (2015). DW. Djeca Sarajeva nisu slučajne žrtve š The children of Sarajevo are not accidental victims]. https://www. dw.com/bs / djeca-sarajeva-nisu-slu \%C4\%8Dajne-\%C5\%BErtverata/a-18496249 (Access Date: 8/10/2020)

- BNN. (2020). Bosnian national network. Sličnosti emocija: Ratna opsada i krunska opsada Sarajeva [Similarities of Emotions: The War Siege and the Crown Siege of Sarajevo]. https://bnn.ba/ vijesti/slicnosti-emocija-ratna-opsada-i-korona-opsada- Sarajevo (Access Date: 22.09.2020)

- BRZEZINSKI, Z. (2007). Washington Post. Terrorized by War. https: / / www.washingtonpost.com/wpdyn/ content/article/2007/03/23/ AR2007032301613.html (Access Date: 22/09/2020)

- CHU-LIEN CHAO, R. (2011). Managing Stress and Maintaining Well-Being: Social Support, Problem-Focused Coping, and Avoidant Coping, Journal of Counseling and Development, 87(2). 338-348.

- CLARK, K. (1980). Civilization. London: BBC Books

- FUREDI, F. (2006). Culture of fear Revisited. New York: Continuum

- GALLUP. (2020). Gallup News. https://news.gallup.com/opinion/ gallup/308126/roundup-gallup-covid- coverage.aspx (Access Date: $20 / 10 / 2020)$

- HADŽIĆ, F. (2020). Politicization of Religion and Sacralization of Balkan Nations Regarding Bosnia and Herzegovina, Occasional Papers on Religion in Eastern Europe, (OPREE), 40(7).105-131.

- HADŽIĆ, F. (2020). Post-Yugoslav spaces between defective democracies, authoritarianism, and kleptocracies, International Affairs and Global Strategy, 86. 38-52.

- HADŽIĆ, F. (2020). The European Union (EU) Political Identity Within the Migrant Crisis, and The Balkan - Bosnian Route; Xenophobia and Religious Identity. Research, Society and Development, 9(10). 1-30.

- HADŽIĆ, F. (2020). The Influence of Social Media on Threats to Identity, Stability and National Security; Institutional Inefficiency and Vulnerability of B\&H. Defendology. 45-46. 65-111. 10.7251/ DEFEN4520067H

- HADŽIĆ, F. (2020). The Political Psychology of Extremism; "Naturalness" of the Phenomenon in the Western Balkans. Technium Social Sciences Journal, 11(1), 250-267.

- JONES, L. (2013). Then they started shooting: Children of the Bosnian War and the adults they become. New York: Bellevue Literary Press

- JUGO, D. (2017). Menadžment kriznog komuniciranja, Zagreb, Školska knjiga
- KARAVELIĆ, V. \& RUJANAC, Z. (2008). Opsada i odbrana Sarajeva 1992.-1995. [Siege and defense of Sarajevo 1992-1995]. Sarajevo: Institut za istraživanje zločina protiv čovječnosti i međunarodnog prava univerziteta u Sarajevu

- MAČEK, I, (2009). Sarajevo under Siege: Anthropology in Wartime. Philadelphia: University of Pennsylvania Press

- MAZOWIECKI, T. (1994). The Sixth Periodic Report on the Situation of Human Rights in the Territory of former Yugoslavia. UN Commission on Human Rights. Geneva: E/CN.4/1994/110,

- MINISTRY OF HEALTH. (2020). Federation of B\&H Report. https: / / www.fmoh.gov.ba

- MUŠIČ, S. (2020). Global analitika. Kroz rad i planiranje, BiH može ublažiti učinke koronavirusa. [Through work and planning, B\&H can mitigate the effects of the coronavirus]. https: / /globalanalitika. com/zajednickim-radom-i-planiranjem-bosna-i-hercegovinamoze-ublaziti-posljedice-korona-virus /

- OSMANOVIĆ, A. \& ZVIZDIĆ, S. (2000). War-related traumatic experiences and psychosomatic reactions of younger adolescents. Sarajevo: The psychosocial consequences of war

- POVRZANOVIĆ, M. (1997). Children, War and Nation: Croatia 1991-4. Journal of Global Child Research. 4(20). 81/101.

- SCHEFFER, M. CHI XU, C. KOHLER, T. LENTON, T. \& SVENNING, J. (2020). Future of the Human Climate Niche. PNAS. 117(21). 11350-11355.

- SLOBODNA EUROPA. (2020). Slobodna Europa. Livno Canton withdrew the decision to ban the entry of B\&H citizens. https:// www.slobodnaevropa.org/a/30503753.html (Access Date: 20/10/2020)

- SNYDER, C. \& DINOFF, B. (1999). In C. R. Snyder (Ed.). Coping: Where Have You Been? Coping: The Psychology of What Works. New York: Oxford University Press.

- SOFTIC, S. (2014). Aljazeera. Meliha Varešanović, žena na fotografiji koja Je očarala svijet [Meliha Varešanović, the woman in the photo who enchanted the world]. http://balkans.aljazeera.net/vijesti/ meliha-varesanovic-zena-sa-fotografije-koja-je- ocarala-svijet (Access Date: 20/10/2020)

- VNIITF. (2020). VNITF. The Second Nuclear Weapon Center of the Soviet Union. http: / / vniitf.ru/en (Access Date: 10/10/2020)

- VUKOJEVIĆ, M. (2010). Dubrovnik u čast, Dubrovnik: Matica Hrvatska

- WORLD HEALTH ORGANIZATION (2019). WHO. Mental Health Conditions in Conflict Situations are Much More. https:/ / www.who.int/ newsroom/ commentaries / detail / mental-healthconditions-in-conflict-situations-are-much-more-widespread-thanwe-thought (Access Date: 24/10/2020) 